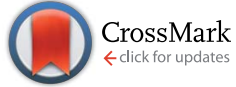

Cite this: RSC Adv., 2015, 5, 51779

\title{
First noscapine glycoconjugates inspired by click chemistry $\dagger$
}

\author{
Kunj B. Mishra, ${ }^{a}$ Ram C. Mishra*b and Vinod K. Tiwari ${ }^{\star a}$
}

Received 22nd April 2015

Accepted 1st June 2015

DOI: $10.1039 / c 5 r a 07321 a$

www.rsc.org/advances

A number of novel 7-O-noscapine glycoconjugates have been synthesized starting from noscapine, an alkaloid found in the opium plant, via two successive steps. The first step is a selective 7-Odemethylation of noscapine and the next is a subsequent propargylation which affords 7-O-propargyl noscapine (3) in good yield. The structure was confirmed by extensive spectroscopic data including single crystal X-ray data. The 1,3-dipolar cycloaddition of the developed noscapine derivative 3 with glycosyl azides $6 a-m$ was investigated to give the triazole-linked second-generation noscapine analogs in their glycoconjugate forms $(8 a-m)$ to augment the therapeutic efficacy of noscapine.

\section{Introduction}

Natural products and their derivatives are now well established biologically relevant moieties and participate in critical roles in modern drug discovery and development. ${ }^{1}$ Alkaloids obtained from nature are the most potent and pharmaceutically interesting scaffolds. ${ }^{2}$ One member of this group, noscapine ('a phthalideisoquinoline alkaloid'), has a benzofuranone ring attached to the hetero ring of isoquinoline. Noscapine is available in about $7 \%$ abundance during opium harvesting. ${ }^{3}$ It has been used as an antitussive agent for several decades because of its favourable toxicity profile. Recently, it was found to bind tubulin and alter its conformation and properties, and alter microtubule dynamics., ${ }^{4,5}$ Additionally, noscapine has also shown the successful inhibition of various neoplasms in vitro as well as in vivo, such as leukaemia and lymphoma, ${ }^{6-8}$ along with melanoma, ${ }^{9}$ ovarian cancer, ${ }^{10}$ gliomas, ${ }^{11}$ and breast, ${ }^{12}$ lung $^{13}$

${ }^{a}$ Department of Chemistry, Centre of Advanced Study, Faculty of Science, Banaras Hindu University, Varanasi-221005, India.E-mail: Tiwari_chem@yahoo.co.in ${ }^{b}$ College of Pharmacy, University of Georgia, USA. E-mail: rcmishra@uga.edu $\dagger$ Electronic supplementary information (ESI) available: Copies of ${ }^{1} \mathrm{H}$ and ${ }^{13} \mathrm{C}$ NMR spectra of all the new compounds and single crystal X-ray data of 3 have been provided. CCDC 1022189. For ESI and crystallographic data in CIF or other electronic format see DOI: 10.1039/c5ra07321a and colon $^{14}$ cancers. Recently, Joshi et al. have assessed the mechanistic path of this anticancer effect after performing several studies where they found that noscapine can perturb tubulin dynamics. ${ }^{15}$ Recent literature has revealed that chemical modifications at its 7-position via selective demethylation on the benzofuranone ring system has been achieved and showed that the $O$-alkylated derivatives, including the 7hydroxyl compounds, were 100-fold more effective than the parent noscapine. ${ }^{16,17}$ This strongly suggests that the presence and modification of the benzofuranone ring in the parent molecule has a significant impact on its biological activity (Fig. 1).

Carbohydrates and their diverse saccharide forms (mono to poly) always attract synthetic chemists for their utilization in medicinal chemistry because their use yields effective control over biological functions. ${ }^{18}$ Additionally, the multivalent nature of carbohydrate molecules is frequently used to enhance their affinities for targets in different biological processes, such as the binding of bacteria, bacterial toxins, galectins and other lectins. ${ }^{19}$ Although the carbohydrates alone demonstrate no therapeutic action, their presence in synthetic and naturally occurring molecules creates a prominent change in their physical, chemical and biological properties. This also influences the biological activity of most of the drugs which incorporate them. ${ }^{20}$

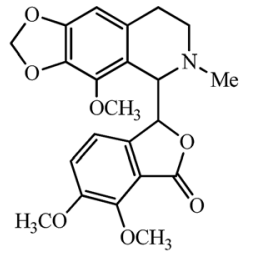

$1 \mathbf{a}$

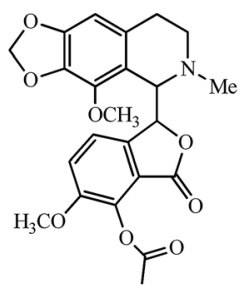

$1 \mathbf{b}$

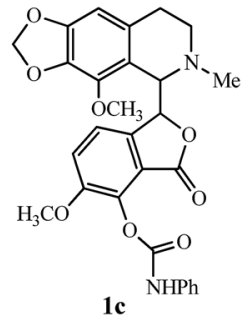

1c
Fig. 1 Structure of noscapine (1a) and its potent biologically active 7$O$-analogs $(1 \mathrm{~b}, 1 \mathrm{c})$, against tubulin polymerization. 


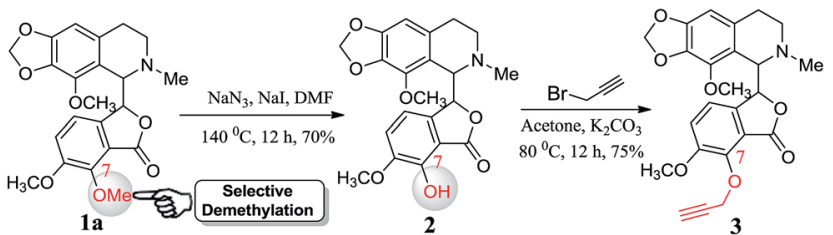

Scheme 1 Synthesis of 7-O-propargyl noscapine derivative via selective demethylation and subsequent propargylation.

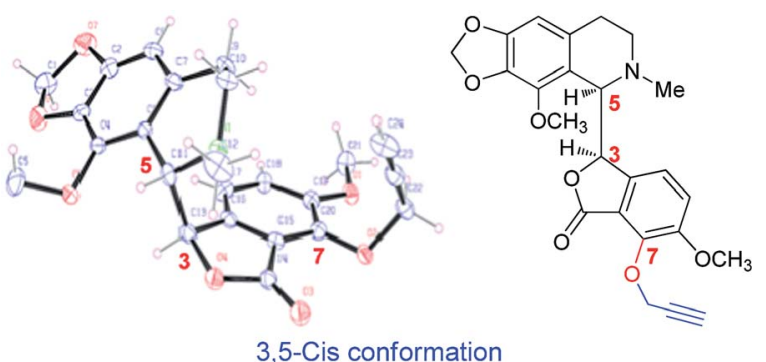

Fig. 2 Molecular structure of 3 . Thermal ellipsoids of $\mathrm{C}, \mathrm{N}$, and $\mathrm{O}$ are set at $40 \%$ probability.

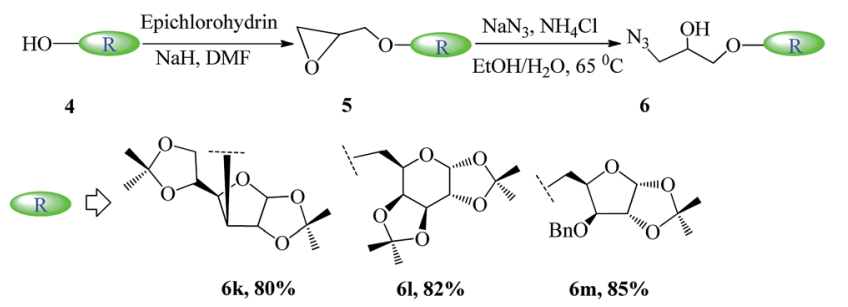

Scheme 2 Synthesis of glycosyl azido alcohols $6 \mathrm{k}-\mathrm{m}$ using orthogonally protected sugars and epichlorohydrin.
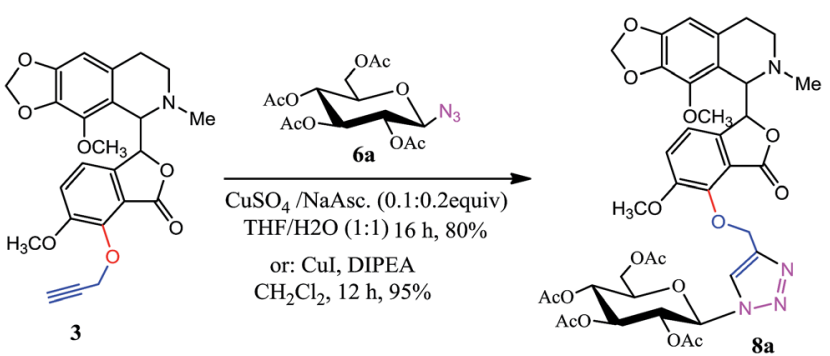

Scheme 3 Optimization of reaction medium and $\mathrm{Cu}(\mathrm{I})$ catalyst for CuAAC reaction of 3 and $6 a$

The $\mathrm{Cu}(\mathrm{I})$-catalysed click reaction ${ }^{\mathbf{2 1 , 2 2}}$ is a precise tool for the joining of two dissimilar moieties having azide and terminal alkyne functionalities and has emerged as an important strategy for the discovery and optimization of leads. This strategy is also being used in the exploration of effective drug candidates against various therapeutic strains. ${ }^{23-28}$ Based upon this impetus and with our previous experience, ${ }^{29-32}$ herein we have successfully incorporated a terminal alkyne functionality in naturally occurring $\alpha$-noscapine at its C-7 position. This strategy afforded novel 7-O-analogs which were further utilized for developing second-generation noscapine derivatives in their glycoconjugate forms using $\mathrm{Cu}(\mathrm{I})$-catalyzed click chemistry. We hope this will satisfy the increasing demand for more potent analogs of this molecule to modulate microtubules more effectively.

\section{Results and discussion}

Our strategy started with the demethylation of the parent compound noscapine. Sodium azide and sodium iodide in dimethylformamide (DMF) were used to cleave the methyl group selectively at position 7 of the benzofuranone ring. ${ }^{17 \boldsymbol{b}}$ Briefly, noscapine was dissolved in anhydrous DMF along with sodium azide and sodium iodide followed by stirring at $140{ }^{\circ} \mathrm{C}$ for $4 \mathrm{~h}$ to obtain 7-hydroxy noscapine 2 (Scheme 1). Compound 2 was then propargylated at its hydroxyl moiety using $\mathrm{K}_{2} \mathrm{CO}_{3}$ in refluxing acetone at $80{ }^{\circ} \mathrm{C}$ to afford 7-O-propargylated noscapine 3 in $75 \%$ yield (Scheme 1). Surprisingly, this reaction did not occur in DMF at room temperature using the same base. Compound 3 served as a scaffold to synthesize various C-7modified derivatives of noscapine $\mathbf{8 a - m}$ in their glycoconjugate form. The structures of the new C-7 analogs of noscapine 3 were deduced from their extensive spectral studies (IR, NMR, and MS). Single crystal X-ray analysis of compound 3 confirmed the selective demethylation of the parent molecule at the C-7 position.

The ${ }^{1} \mathrm{H}$ NMR spectrum of compound 3 exhibited one singlet signal at $\delta 2.62$, merged with the 3 protons of $\mathrm{N}-\mathrm{Me}$, which was assigned to the acetylene proton. Shifting of the ortho-coupled aromatic protons from $\delta 5.11(\mathrm{~d}, J=8.4 \mathrm{~Hz})$ to $6.10(\mathrm{~d}, J=8.4$ $\mathrm{Hz}$ ) for C-9 and from $\delta 6.44(\mathrm{~d}, J=8.4 \mathrm{~Hz})$ to $6.96(\mathrm{~d}, J=8.4 \mathrm{~Hz})$ for C-10 also confirmed the substitution at the 7-hydroxy group. In addition to other signals, the appearance of a multiplet at $\delta$ 5.05 attributed to $\mathrm{OCH}_{2}$ finally confirmed the addition of the propargyl group, leading to the formation of compound 3. In the ${ }^{13} \mathrm{C}$ NMR, two new resonances were observed at $\delta 81.9$ and $\delta$ 75.4 which were assigned to both acetylene carbons. The molecular structure of compound 3 was also confirmed by single crystal X-ray analysis (Fig. 2, see ESI Table $1 \dagger$ ).

Once we achieved the second generation (C-7) noscapine analogue 3, having one terminal alkyne, we attempted the synthesis of various sugar azides for glycoconjugation of the novel noscapine derivative. We prepared sugar azides with the economical and readily available monosaccharides, i.e. $\mathrm{D}^{-}$ glucose, D-galactose, D-xylose and a disaccharide, lactose, which, after processing through a number of high-yielding steps involving protections and diverse modifications, afforded deoxy-azido sugars $\mathbf{6 a - j}$ in good yields. ${ }^{33}$ The sugar azides $\mathbf{6 k - m}$ were synthesised via a substitution reaction on the orthogonally protected carbohydrate with epichlorohydrin in the presence of $\mathrm{NaH}$ in dry DMF at $0{ }^{\circ} \mathrm{C}-$ r.t., which afforded a diastereoisomeric mixture of glycosyl epoxides $\mathbf{5 k}-\mathbf{m}$. These epoxides, on reaction with $\mathrm{NaN}_{3}$ and $\mathrm{NH}_{4} \mathrm{Cl}$ in EtOH/ $\mathrm{H}_{2} \mathrm{O}$ at $65{ }^{\circ} \mathrm{C}$, afforded their respective O-substituted glycosyl azido alcohols 6k-m (Scheme 2). 
Table 1 Synthesis of 7-O-Noscapine glycoconjugates $8 \mathrm{a}-\mathrm{m}$ via $\mathrm{Cu}$-catalyzed click chemistry

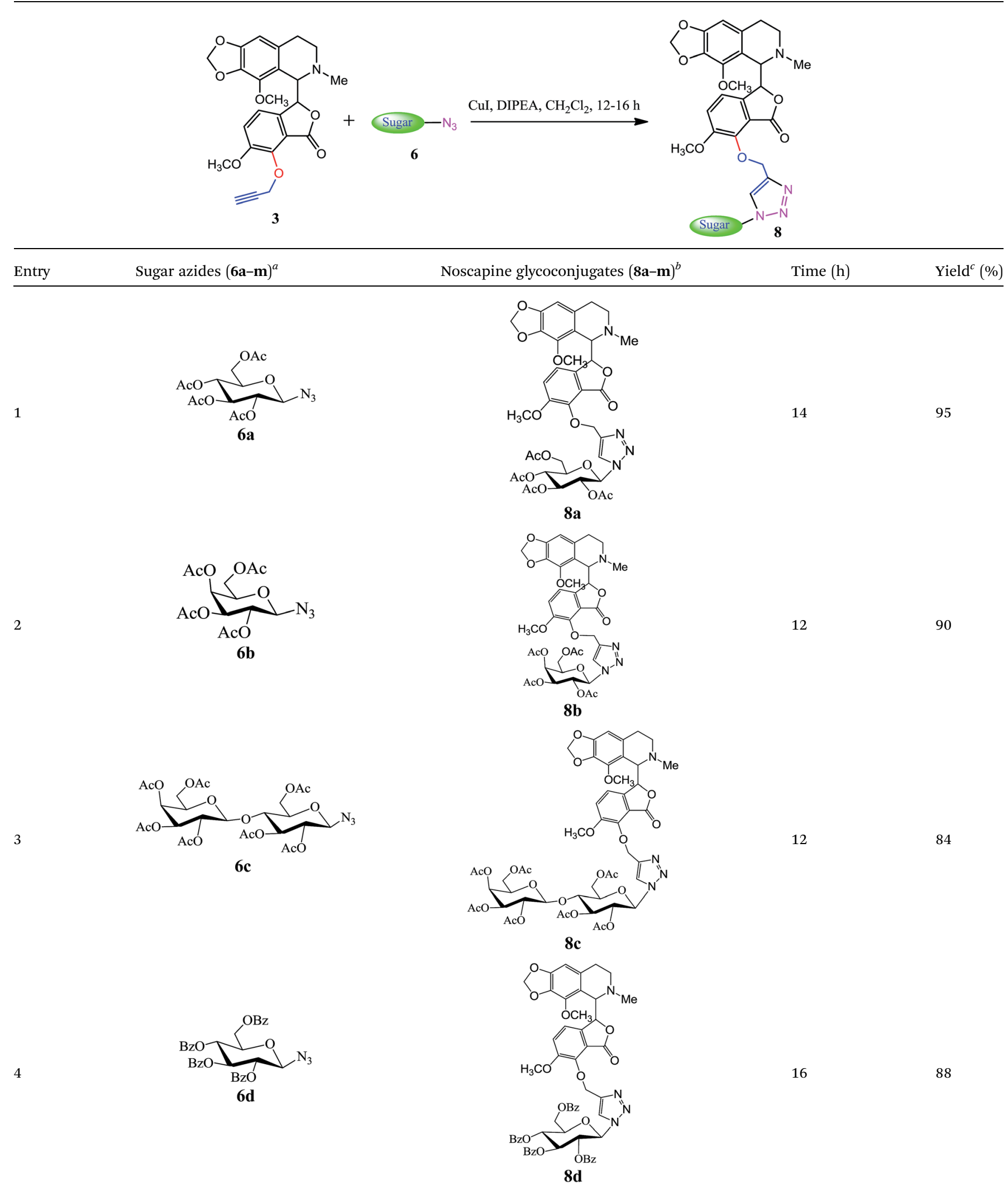


Table 1 (Contd.)

5

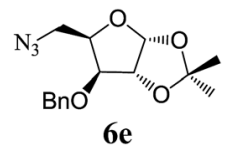

6
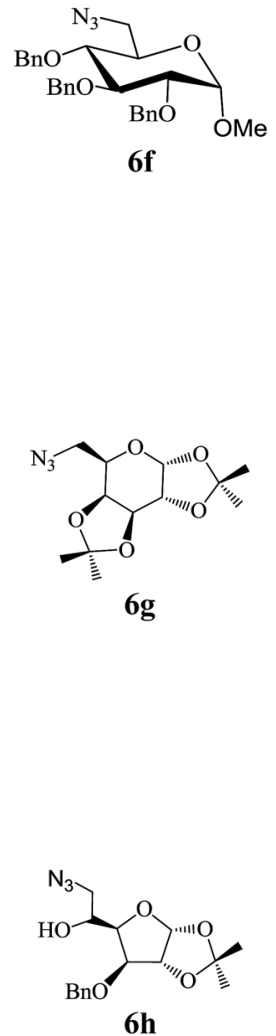

9

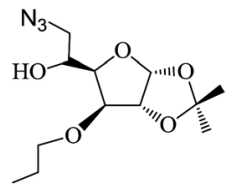

6i

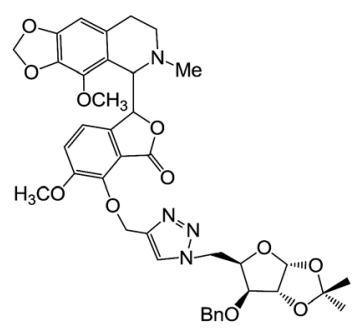

$8 \mathrm{e}$
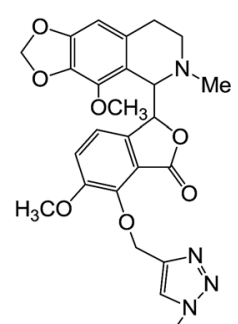

14

85

15

90

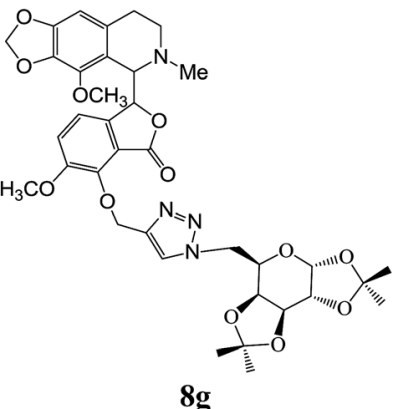

$8 \mathrm{~g}$

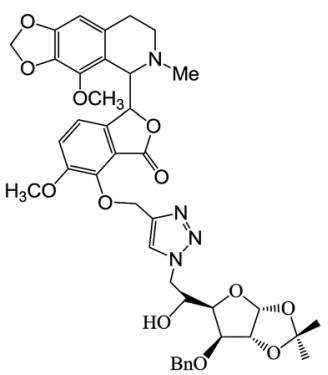

$8 h$

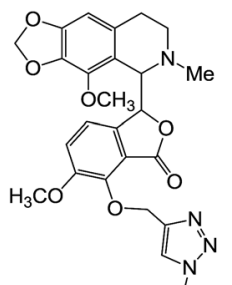

12

85 
10

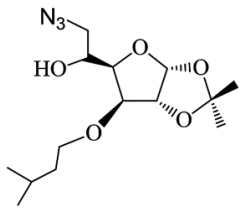

6j

11
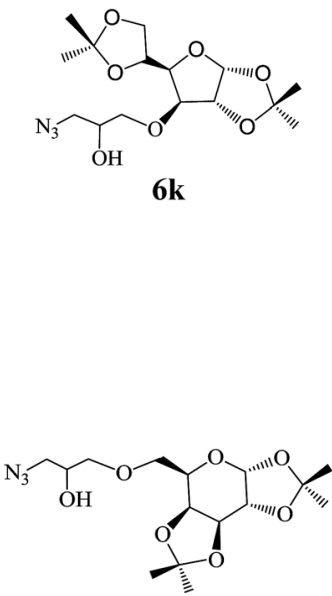

61

13

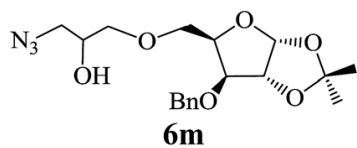

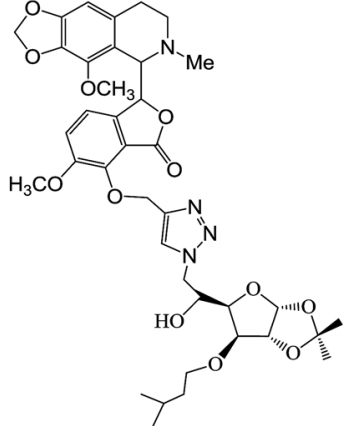

8j

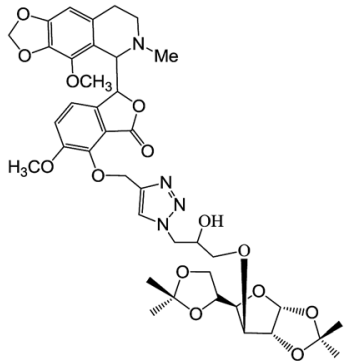

$8 k$

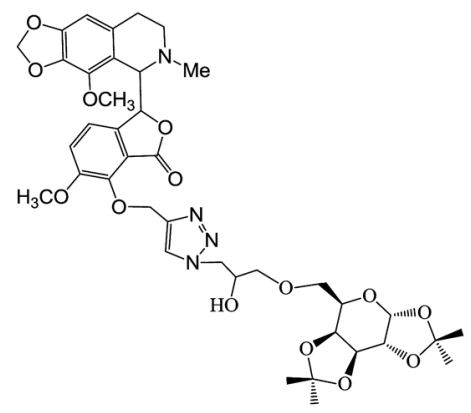

81

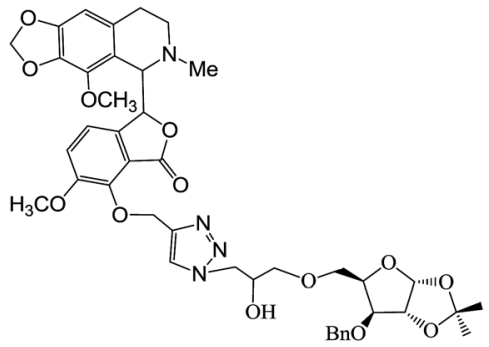

$8 \mathrm{~m}$

${ }^{a}$ Molar ratios: deoxy-azido sugar (1.0 equiv.), 7-O-propargylated noscapine (1.0 equiv.), CuI (0.5 equiv.) and DIPEA (1.0 equiv.). ${ }^{b}$ Noscapine glycoconjugates. ${ }^{c}$ Isolated yield by column chromatography $\left(\mathrm{SiO}_{2}\right)$.

All the developed azidosugars 6a-m underwent glycoconjugation using compound 3 via the copper-catalyzed azide-alkyne click reaction. Generally, copper-catalyzed azidealkyne click reactions require the presence of $\mathrm{Cu}(\mathrm{I})$ species which may be provided directly or in situ depending on the catalyst. Hence, we carried out the reaction using both methods, first using CuI/DIPEA in dichloromethane and then $\mathrm{CuSO}_{4^{-}}$ $\cdot 5 \mathrm{H}_{2} \mathrm{O} /$ sodium ascorbate in aqueous medium. We preferred the former reaction system due to its better yield and shorter reaction time (Scheme 3). Hence, the click reaction of deoxyazido sugar 6a $(0.19 \mathrm{mmol})$ with $3(0.16 \mathrm{mmol})$ in the presence of $\mathrm{CuI}(0.08 \mathrm{mmol})$ and DIPEA $(0.16 \mathrm{mmol})$ was carried out in anhydrous $\mathrm{CH}_{2} \mathrm{Cl}_{2}$ under argon atmosphere at ambient temperature to afford 7-O-noscapine triazolyl glycoconjugate 8a regioselectively in $95 \%$ yield. The regioisomeric nature of compound 8a was established based on its spectroscopic data 
(IR, MS, ${ }^{1} \mathrm{H}$ NMR and ${ }^{13} \mathrm{C} \mathrm{NMR}$ ) and the purity (evidenced by HRMS) is in close agreement with calculated values.

In the ${ }^{1} \mathrm{H}$ NMR spectrum, two doublets and one singlet of the aromatic protons resonated at $\delta 6.95(\mathrm{~d}, J=8.4 \mathrm{~Hz}), 6.07(\mathrm{~d}, J=$ $8.4 \mathrm{~Hz}$ ) and $\delta 6.30$, along with a triazolyl proton singlet observed at $\delta$ 8.25. The anomeric proton of the glucopyranose sugar resonated as a doublet at $\delta 5.86(J=9.6 \mathrm{~Hz})$, while four other sugar protons, along with one noscapine and two oxymethylene protons, appeared at their usual chemical shift values, i.e. between $\delta 5.60-5.22$. Two singlets of methyl protons appeared at $\delta 4.03,3.84$ and were established as the methoxy signals present at the aromatic rings of noscapine and another singlet at $\delta 2.54$ was established as the $\mathrm{N}$-Me protons of the hetero carbon ring. The twelve protons of the acetyl moieties on the sugar scaffold were observed as four singlets having three protons each at $\delta$ 2.10, 2.07, 2.04 and 1.85. A total of seven remaining protons of noscapine were assigned at $\delta 5.93(\mathrm{~s}, 2 \mathrm{H}), 4.40(\mathrm{~d}, J=3.9 \mathrm{~Hz}$, $1 \mathrm{H}), 2.33(\mathrm{~m}, 2 \mathrm{H})$, one merged with the acetyl protons and the last one with the $N$-methyl protons. One of the remaining sugar protons in compound 8a resonated at $\delta 4.28(\mathrm{dd}, J=4.8 \& 12.6$ $\mathrm{Hz}$ ) and the next one appeared as a multiplet at $\delta 4.16$, which confirms the structure.

Further, having established the reaction conditions for the regioselective cycloaddition of the 7-O-propargyl noscapine 3, we explored the scope of other sugar azides in this cycloaddition and prepared a library of 7-O-noscapine triazolyl glycoconjugates $\mathbf{8 b}-\mathbf{m}$ in efficient yields (Table 1 ). Using extensive spectral studies (IR, MS, ${ }^{1} \mathrm{H}$, and ${ }^{13} \mathrm{C} \mathrm{NMR}$ ), the structures of all the developed noscapine glycoconjugates $\mathbf{8 a - m}$ were elucidated.

\section{Weak interactions in compound 3 and their biological importance via stabilisation of geometrical conformations}

Noncovalent inter- and intramolecular interactions play a subtle role in molecular recognition and conformational
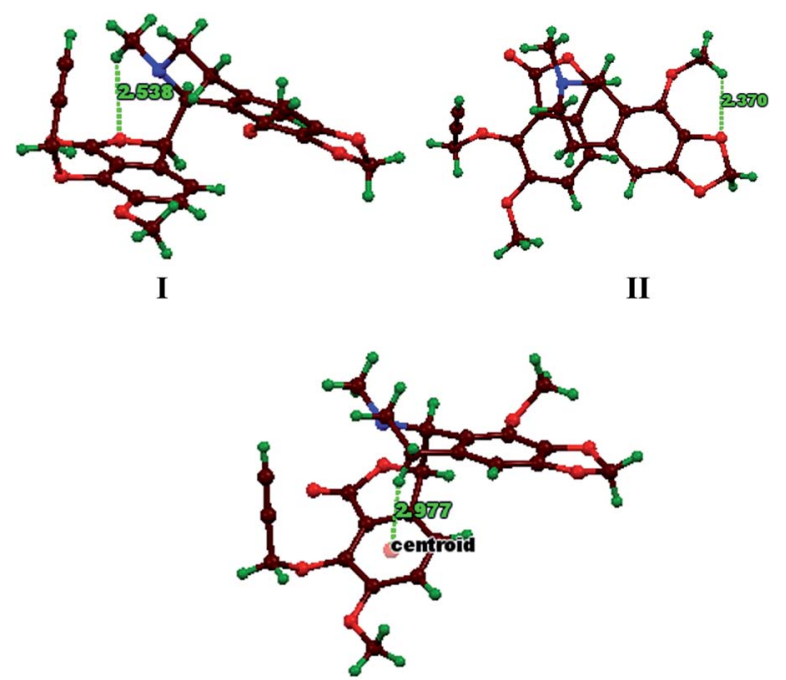

III

Fig. 3 Intramolecular $\mathrm{CH} \cdots \mathrm{O}$ and $\mathrm{CH} \cdots \pi$ interactions. Weak interactions are represented by broken light green lines. Carbon atoms are colored brown, hydrogen atoms green, oxygen atoms red, and nitrogen atoms blue. stabilization within the crystal lattice for biological assays. ${ }^{34,35}$ Therefore, it is important to quantify the various interactions within the molecules in the crystal structures. Compound 3 is rich in $\mathrm{C}-\mathrm{H}$ donors and $\mathrm{O}, \pi$ acceptors. In the isoquinoline ring, the $N$-methyl hydrogens, methylene hydrogens and also the acetylene acidic hydrogen act as a donor whenever oxygen atoms and the $\pi$-electron ring system act as acceptors. Intramolecular and intermolecular $\mathrm{CH} \cdots \mathrm{O}$ and $\mathrm{CH} \cdots \pi$ interactions stabilize the geometry of the molecule and show their effects in the relative changes in the geometrical conformations of compound 3.

These weak interactions generate a number of six member ring systems which were known for their crucial role in biological activities. ${ }^{35}$ Intramolecular interactions have been shown with two six member ring along with a $\mathrm{CH} \cdots \pi$ ring system.

Out of various types of intramolecular interactions (Fig. 3), three of them that cause conformational changes have been presented. A $\mathrm{CH} \cdots \mathrm{O}$ (I) interaction between the $\mathrm{N}$-methyl hydrogens and furanone ring oxygen, with a measured distance of $2.538 \AA$, and a $\mathrm{CH} \cdots \pi$ (III) interaction between the methylene hydrogen of quinoline and aromatic system fused with the

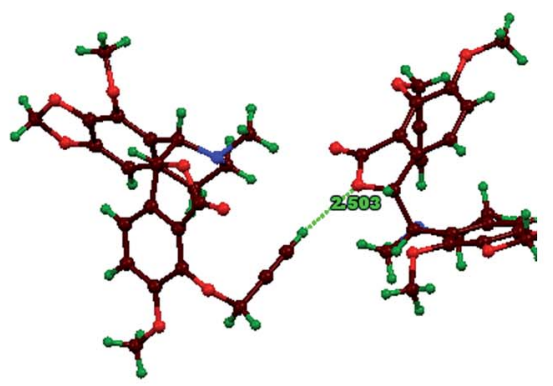

1V
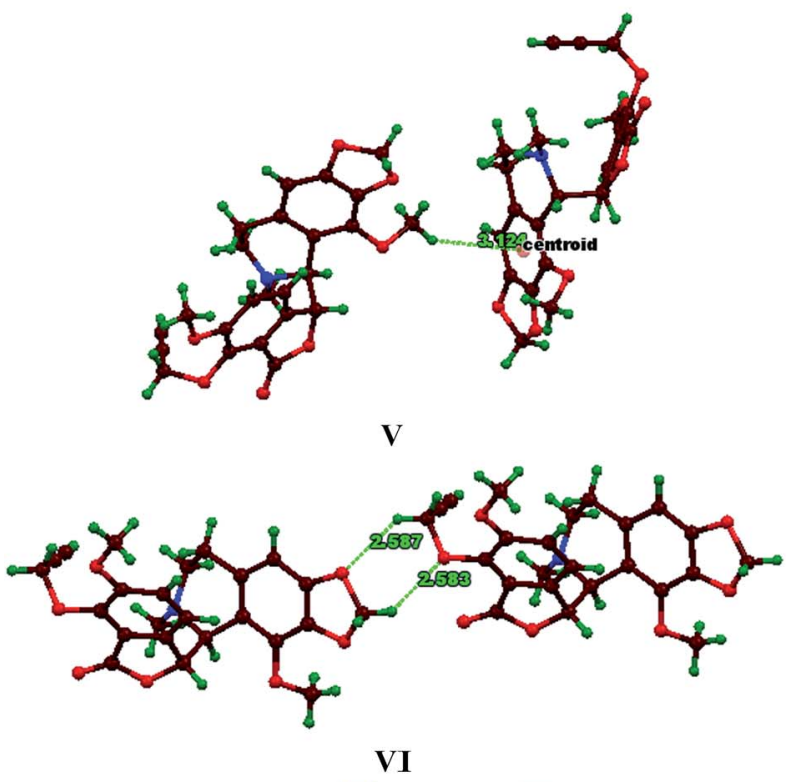

Fig. 4 Intermolecular $\mathrm{CH} \cdots \mathrm{O}$ and $\mathrm{CH} \cdots \pi$ interactions. Weak interactions are represented by broken light green lines. Carbon atoms are brown, hydrogen atoms green, oxygen atoms red, and nitrogen atoms blue. 
lactone ring, with a measured distance of $2.977 \AA$, are attempting to place both of the fused ring systems in parallel planes, but the repulsion between the oxygen lone pairs of both fused ring systems pushes them to their maximum distances and overcomes the effect of a possible $\pi \cdots \pi$ interaction between both of the benzene rings. One of the $\mathrm{CH} \cdots \mathrm{O}$ (II) interactions, with a measured distance of $2.37 \AA$, generates a sixmembered ring system. All these weak interactions confirm the efficacy of the developed molecules in a biological system due to the presence of a number of interacting sites, which create the effect of interacting with problematic enzymes and proteins to reduce their activities during clinical treatment. ${ }^{36}$ Also, intermolecular interactions within the crystal packing have an effect on geometrical conformations and form dimeric structures. The dimeric structures (IV, V, VI) appeared in three forms depending on the type of interactions and the positions of their sites (Fig. 4).

Substitution at the C-7 position in the parent noscapine scaffold creates new interaction sites, such as $\mathrm{CH} \cdots \mathrm{O}$, with measured distances of $2.503 \AA$ (IV) and $2.587 \AA$ (VI), between the acetylene and methylene hydrogens of the adjoining part and the oxygen of the parent molecule. An intermolecular $\mathrm{CH} \cdots \pi$ $(2.503 \AA, V)$ interaction has effects on the conformations in the crystal packing. Thus, the creation of new binding sites in noscapine C-7 analog 3 is evidenced for the well-known potency towards modulating tublin polymerization. Furthermore, because of the multivalent nature of carbohydrates, ${ }^{\mathbf{1 8}}$ their introduction to noscapine is envisaged to provide more binding sites and could result in increased efficacy; however, continued efforts are required for the conclusive investigation to this end.

\section{Conclusion}

In conclusion, a number of sugar azides were prepared and further subjected to a $\mathrm{Cu}(\mathrm{I})$-catalyzed azide alkyne cycloaddition reaction (click) with 7-O-propargylated noscapine. We have developed thirteen second generation noscapine triazolyl glycoconjugates at the C-7 position in good to excellent yields. Also, the role of weak interactions has been correlated with the biological action of noscapine analogs. The methodology is efficient for the preparation of modified conjugates of noscapine to improve its therapeutic efficacy and its pharmacological properties. Further research into the development of noscapine glycoconjugates as potential anti-cancer agents is in progress in our laboratory.

\section{Experimental}

\section{General methods}

All of the reactions were performed in anhydrous solvents (where required) under an argon atmosphere in oven dried glassware at $100{ }^{\circ} \mathrm{C}$. All reagents and solvents were of pure analytical grade. Thin-layer chromatography (TLC) was performed on $60 \mathrm{~F}_{254}$ silica gel, pre-coated on aluminum plates, and revealed with either a UV lamp $\left(\lambda_{\max }=254 \mathrm{~nm}\right)$, a specific colour reagent (Draggendorff reagent or iodine vapour) or by spraying with methanolic- $\mathrm{H}_{2} \mathrm{SO}_{4}$ solution and subsequent charring by heating at $100{ }^{\circ} \mathrm{C} .{ }^{1} \mathrm{H}$ and ${ }^{13} \mathrm{C}$ NMR were recorded at 300 and $75 \mathrm{MHz}$, respectively. Chemical shifts are given in ppm downfield from internal TMS; $J$ values are in Hz. The high resolution mass spectrometry (HRMS) was carried out using electrospray ionization mass spectrometry. The infrared spectra were recorded as Nujol mulls on $\mathrm{KBr}$ plates. Single-crystal X-ray data were collected on an Xcalibur Eos (Oxford) CCDdiffractometer.

General procedure for synthesis of sugar azides $(6 \mathbf{a}-\mathbf{g})$. The compounds 6a-g were prepared from readily available carbohydrates (D-glucose, D-galactose, and D-ribose etc.) using standard protection and modification methodologies. ${ }^{33}$

General procedure for the synthesis of glycosyl epoxides (5k$\mathbf{m})$. A solution of orthogonally protected sugar $\mathbf{4 k - \mathbf { m }}$ having one free hydroxyl group ( $1.0 \mathrm{mmol}$ ) in anhydrous DMF was cooled to $0{ }^{\circ} \mathrm{C}$ and sodium hydride (2.0 equiv.) was added portion-wise. The reaction mixture was stirred at $0{ }^{\circ} \mathrm{C}$ under argon atmosphere for 20 minutes. Epichlorohydrin $(1.2 \mathrm{mmol})$ was added at $0{ }^{\circ} \mathrm{C}$ and allowed to stir for 12 hour at room temperature. Upon completion of the reaction, the remaining sodium hydride was quenched with water; the solvent was removed under reduced pressure followed by extraction with ethyl acetate. The combined organic layer was washed with brine solution, dried over anhydrous $\mathrm{Na}_{2} \mathrm{SO}_{4}$, filtered and concentrated under reduced pressure to get the crude product. Purification using flash chromatography (ethyl acetate $/ n$-hexane) afforded the desired glycosyl epoxide $5 \mathbf{k}-\mathbf{m}$.

General procedure for the synthesis of glycosyl azido alcohols 6k-m. A solution of glycosyl epoxide 5k-m in $\mathrm{EtOH}-\mathrm{H}_{2} \mathrm{O}$ (1:1) was treated with $\mathrm{NaN}_{3}$ and $\mathrm{NH}_{4} \mathrm{Cl}$ at $65{ }^{\circ} \mathrm{C}$ for $8 \mathrm{~h}$. Upon completion of the reaction, the solvent was removed under reduced pressure, and extracted with ethyl acetate and water. The organic layer was dried over anhydrous $\mathrm{Na}_{2} \mathrm{SO}_{4}$, filtered, and concentrated under vacuum, followed by flash chromatography (ethyl acetate/hexane) affording the desired glycosyl azido alcohol 6k-m in good yield.

General procedure for 7-O-propargyl noscapine 3. To a stirring solution of compound $2(1.0 \mathrm{~g}, 2.5 \mathrm{mmol})$ in dry acetone ( 25 $\mathrm{mL}$ ), propargyl bromide $(0.291 \mathrm{~mL}, 3.2 \mathrm{mmol})$ and $\mathrm{K}_{2} \mathrm{CO}_{3}(690$ $\mathrm{mg}, 5.0 \mathrm{mmol}$ ) were added at room temperature. The reaction was fitted with a water condenser and refluxed at $80{ }^{\circ} \mathrm{C}$ under inert conditions for $12 \mathrm{~h}$. After completion of the reaction (monitored by TLC), the reaction mixture was concentrated in vacuo, extracted with $\mathrm{CH}_{2} \mathrm{Cl}_{2}(2 \times 50 \mathrm{~mL})$ and washed with $\mathrm{H}_{2} \mathrm{O}$ $(10 \mathrm{~mL})$. The organic layer was separated and dried over anhydrous $\mathrm{Na}_{2} \mathrm{SO}_{4}$, and the solvent evaporated under reduced pressure followed by purification (flash column chromatography using gradient mixtures of $n$-hexane/ethyl acetate) to afford compound 3 as a yellowish solid ( $819 \mathrm{mg}$, yield 75\%). IR (KBr) $\nu_{\text {max }}: 2949,2850,1753,1622,1514,1497,1479,1362,1243$, $1033 \mathrm{~cm}^{-1}$; MS: $m / z 457[\mathrm{M}+\mathrm{Na}] ;{ }^{1} \mathrm{H}$ NMR $\left(300 \mathrm{MHz}, \mathrm{CDCl}_{3}\right): \delta$ $6.97(\mathrm{~d}, J=8.4 \mathrm{~Hz}, 1 \mathrm{H}), 6.29(\mathrm{~s}, 1 \mathrm{H}), 6.10(\mathrm{~d}, J=8.1 \mathrm{~Hz}, 1 \mathrm{H}), 5.93$ $(\mathrm{s}, 2 \mathrm{H}), 5.58(\mathrm{~d}, J=4.2 \mathrm{~Hz}, 1 \mathrm{H}), 5.05(\mathrm{~s}, 2 \mathrm{H}), 4.39(\mathrm{~d}, J=4.2 \mathrm{~Hz}$, $1 \mathrm{H}), 4.03(\mathrm{~s}, 3 \mathrm{H}), 3.86(\mathrm{~s}, 3 \mathrm{H}), 2.62-2.54(\mathrm{~m}, 4 \mathrm{H}), 2.40-2.30(\mathrm{~m}$, $3 \mathrm{H}), 1.90-1.86(\mathrm{~m}, 1 \mathrm{H}) ;{ }^{13} \mathrm{C} \mathrm{NMR}\left(75 \mathrm{MHz}, \mathrm{CDCl}_{3}\right): \delta$ 168.0, 152.7 , 148.3, 140.9, 140.4, 133.9, 132.1, 120.8, 118.5, 118.4, 
118.1, 117.0, 102.3, 102.2, 100.7, 81.9, 81.8, 75.4, 62.5, 61.2, 60.7, 56.9, 49.9, 46.2, 27.9 ppm.

General procedure for the synthesis of noscapine glycoconjugates (8a-m)

Noscapine glycoconjugate $8 \boldsymbol{a}$. To a stirring solution of compound 3 (70 $\mathrm{mg}, 0.16 \mathrm{mmol})$ and azido-sugar $6 \mathbf{6}(71 \mathrm{mg}$, $0.19 \mathrm{mmol})$ in anhydrous $\mathrm{CH}_{2} \mathrm{Cl}_{2}(10 \mathrm{~mL})$, CuI $(15 \mathrm{mg}, 0.08$ $\mathrm{mmol})$ and DIPEA $(0.027 \mathrm{ml}, 0.16 \mathrm{mmol})$ were added and stirring was continued at room temperature for $14 \mathrm{~h}$ under argon atmosphere. After completion of the reaction (monitored by TLC), the reaction mixture was concentrated in vacuo to obtain a crude residue which was purified using silica gel (230-400 mesh) column chromatography (ethyl acetate $/ n$-hexane) to afford the desired noscapine glycoconjugate $8 \mathbf{a}$ as a brown solid (124 mg, yield 95\%); $R_{\mathrm{f}}=0.35$ (60\% ethyl acetate $/ n$-hexane); IR (KBr) $\mathrm{cm}^{-1}$ : 2960, 2854, 1756, 1622, 1497, 1479, 1377, 1225, 1037; ${ }^{1} \mathrm{H}$ NMR (300 MHz, $\left.\mathrm{CDCl}_{3}\right): \delta 8.25(\mathrm{~s}, 1 \mathrm{H}), 6.95(\mathrm{~d}, J=8.4$ $\mathrm{Hz}, 1 \mathrm{H}), 6.30(\mathrm{~s}, 1 \mathrm{H}), 6.07$ (d, $J=8.1 \mathrm{~Hz}, 1 \mathrm{H}), 5.93-5.84(\mathrm{~m}, 3 \mathrm{H})$, $5.60-5.24(\mathrm{~m}, 7 \mathrm{H}), 4.40(\mathrm{~d}, J=3.9 \mathrm{~Hz}, 1 \mathrm{H}), 4.28(\mathrm{dd}, J=4.8$ and $12.6 \mathrm{~Hz}, 1 \mathrm{H}), 4.16-4.08(\mathrm{~m}, 1 \mathrm{H}), 4.03$ (m, 3H), 3.84 (s, 3H), 2.54 (m, 4H), $2.33(\mathrm{~m}, 2 \mathrm{H}), 2.10-2.03(\mathrm{~m}, 10 \mathrm{H}), 1.85(\mathrm{~s}, 3 \mathrm{H}) ;{ }^{13} \mathrm{C}$ NMR $\left(75 \mathrm{MHz}, \mathrm{CDCl}_{3}\right): \delta 170.5,170.0,169.2,168.6,168.2,152.3$, $148.3,145.4$, 140.8, 140.4, 132.1, 133.4, 122.6, 120.6, 118.2, 118.1, 116.9, 102.3, 102.2, 100.8, 85.5, 81.8, 74.9, 72.8, 70.2, 67.6, 67.6, 60.8, 60.6, 59.3, 56.6, 50.0, 46.3, 28.1, 20.6, 20.5, 20.4, 20.1 ppm; HRMS: calcd for $\mathrm{C}_{38} \mathrm{H}_{43} \mathrm{~N}_{4} \mathrm{O}_{16}[\mathrm{M}+\mathrm{H}]$ : 811.2674; found 811.2671.

Noscapine glycoconjugate $8 \boldsymbol{b}$. Compound 3 (50 $\mathrm{mg}, 0.11$ $\mathrm{mmol})$, on treatment with azido-sugar $6 \mathbf{b}(51 \mathrm{mg}, 0.13 \mathrm{mmol})$, DIPEA (0.018 ml, $0.13 \mathrm{mmol})$ and CuI (10 mg, $0.05 \mathrm{mmol})$ in dry $\mathrm{CH}_{2} \mathrm{Cl}_{2}(10 \mathrm{~mL})$ at room temperature under argon atmosphere for $12 \mathrm{~h}$ and workup as described in the general procedure, afforded compound $\mathbf{8 b}$ as a brown solid ( $80 \mathrm{mg}$, yield $90 \%) ; R_{\mathrm{f}}=$ 0.3 (60\% ethyl acetate/ $n$-hexane); IR (KBr) $\mathrm{cm}^{-1}: 3454,2924$, 2853, 1755, 1622, 1498, 1479, 1460, 1371, 1218; ${ }^{1} \mathrm{H}$ NMR (300 $\left.\mathrm{MHz}, \mathrm{CDCl}_{3}\right): \delta 8.22(\mathrm{~s}, 1 \mathrm{H}), 6.88(\mathrm{~d}, J=8.4 \mathrm{~Hz}, 1 \mathrm{H}), 6.23(\mathrm{~s}, 1 \mathrm{H})$, $6.02(\mathrm{~d}, J=8.1 \mathrm{~Hz}, 1 \mathrm{H}), 5.86(\mathrm{~s}, 2 \mathrm{H}), 5.76(\mathrm{~d}, J=9.3 \mathrm{~Hz}, 1 \mathrm{H})$, 5.61-5.22 (m, 4H), 5.19-5.15 (m, 2H), 4.34 (d, $J=3.6 \mathrm{~Hz}, 1 \mathrm{H})$, 4.14-4.05 (m, 3H), $3.94(\mathrm{~s}, 3 \mathrm{H}), 3.77(\mathrm{~s}, 3 \mathrm{H}), 2.47(\mathrm{~m}, 4 \mathrm{H}), 2.26-$ $2.18(\mathrm{~m}, 4 \mathrm{H}), 1.98-1.94(\mathrm{~m}, 7 \mathrm{H}), 1.79(\mathrm{~m}, 3 \mathrm{H}) ;{ }^{13} \mathrm{C} \mathrm{NMR}(75 \mathrm{MHz}$, $\left.\mathrm{CDCl}_{3}\right): \delta 170.2,170.1,169.8,168.7,168.1,152.4,148.3,145.2$, $140.8,140.3$, 133.9, 132.0, 122.6, 120.6, 118.1, 116.7, 102.3, 102.1, 100.7, 86.2, 81.9, 73.8, 70.9, 67.7, 67.5, 66.7, 61.2, 60.6, 59.2, 56.5 49.8, 46.1, 27.9, 20.6, 20.5, 20.4, 20.1 ppm; HRMS: calcd for $\mathrm{C}_{38} \mathrm{H}_{43} \mathrm{~N}_{4} \mathrm{O}_{16}[\mathrm{M}+\mathrm{H}]$ : 811.2674; found 811.2670.

Noscapine glycoconjugate $8 c$. Compound $3(50 \mathrm{mg}, 0.11$ $\mathrm{mmol})$, on treatment with azido-sugar $6 \mathrm{c}(90 \mathrm{mg}, 0.13 \mathrm{mmol})$, DIPEA (0.018 ml, $0.13 \mathrm{mmol})$ and CuI (10 mg, $0.05 \mathrm{mmol})$ in dry $\mathrm{CH}_{2} \mathrm{Cl}_{2}(10 \mathrm{~mL})$ at room temperature under argon atmosphere for $12 \mathrm{~h}$ and workup as described in the general procedure, afforded compound 8c as a brown solid (101 $\mathrm{mg}$, yield 84\%); $R_{\mathrm{f}}=0.3$ (80\% ethyl acetate $/ n$-hexane); IR (KBr) cm $\mathrm{cm}^{-1}: 3472,2955$, 2925, 2853, 1755, 1622, 1498, 1480, 1456, 1371, 1227, 1046; MS: $m / z 1122[\mathrm{M}+\mathrm{Na}]^{+} ;{ }^{1} \mathrm{H}$ NMR (300 $\left.\mathrm{MHz}, \mathrm{CDCl}_{3}\right): \delta 8.27(\mathrm{~s}, 1 \mathrm{H})$, $6.97(\mathrm{~d}, J=8.1 \mathrm{~Hz}, 1 \mathrm{H}), 6.30(\mathrm{~s}, 1 \mathrm{H}), 5.93(\mathrm{~s}, 2 \mathrm{H}), 5.82(\mathrm{~d}, J=9.0$ $\mathrm{Hz}, 1 \mathrm{H}), 5.63$ (d, $J=3.3 \mathrm{~Hz}, 1 \mathrm{H}), 5.48-5.37$ (m, 6H), 5.17-5.11 (m, 1H), 4.98 (dd, $J=3.3 \mathrm{~Hz}, 10.8 \mathrm{~Hz}, 1 \mathrm{H}), 4.55-4.46(\mathrm{~m}, 3 \mathrm{H})$,
4.17-4.08 (m, 3H), $4.02(\mathrm{~m}, 1 \mathrm{H}), 3.98(\mathrm{~s}, 3 \mathrm{H}), 3.93-3.88(\mathrm{~m}, 2 \mathrm{H})$, $3.85(\mathrm{~s}, 3 \mathrm{H}), 2.67-2.55(\mathrm{~m}, 4 \mathrm{H}), 2.46-2.38(\mathrm{~m}, 3 \mathrm{H}), 2.16,2.12$, 2.09, 2.06, 2.04, 1.97, 1.84 (each s, 21H); ${ }^{13} \mathrm{C}$ NMR (75 MHz, $\left.\mathrm{CDCl}_{3}\right): 170.3,170.0,169.5,169.0,168.8,152.4,148.7,145.2$, 140.2 , 133.9, 131.9, 122.8, 120.2, 118.4, 115.3, 102.3, 102.2, 100.9, 100.8, 85.4, 75.7, 75.6, 72.73, 70.8, 70.7, 70.7, 69.0, 67.5, 66.5, 61.7, 60.7, 60.6, 56.7, 48.9, 45.0, 20.6, 20.6 ppm.

Noscapine glycoconjugate $8 \boldsymbol{d}$. Compound $3(50 \mathrm{mg}, 0.11$ $\mathrm{mmol})$, on treatment with azido-sugar $6 \mathrm{~d}$ (80 $\mathrm{mg}, 0.13 \mathrm{mmol})$, DIPEA (0.018 ml, $0.13 \mathrm{mmol})$ and CuI (10 mg, $0.05 \mathrm{mmol})$ in dry $\mathrm{CH}_{2} \mathrm{Cl}_{2}(10 \mathrm{~mL})$ at room temperature under argon atmosphere for $16 \mathrm{~h}$ and workup as described in the general procedure, afforded compound 8d as a brown solid (102 mg, yield 88\%); $R_{\mathrm{f}}=0.25$ (60\% ethyl acetate $/ n$-hexane); MS: $m / z 1081[\mathrm{M}+\mathrm{Na}]^{+}$; IR (KBr) cm ${ }^{-1}: 3444,3065,2925,2852,2798,1738,1621,1584$, 1496, 1452, 1269; ${ }^{1} \mathrm{H}$ NMR (300 MHz, $\mathrm{CDCl}_{3}$ ): $\delta 8.34$ (s, 1H), 8.01 $(\mathrm{d}, J=7.2 \mathrm{~Hz}, 2 \mathrm{H}), 7.92(\mathrm{~d}, J=7.2 \mathrm{~Hz}, 2 \mathrm{H}), 7.82(\mathrm{~d}, J=7.2 \mathrm{~Hz}$, $2 \mathrm{H}), 7.73(\mathrm{~d}, J=7.2 \mathrm{~Hz}, 2 \mathrm{H}), 7.54-7.35(\mathrm{~m}, 9 \mathrm{H}), 7.30-7.28(\mathrm{~m}$, $3 \mathrm{H}), 6.85(\mathrm{~d}, J=8.1 \mathrm{~Hz}, 1 \mathrm{H}), 6.32-6.23(\mathrm{~m}, 2 \mathrm{H}), 6.09-6.06(\mathrm{~m}$, $3 \mathrm{H}), 5.92-5.82(\mathrm{~m}, 3 \mathrm{H}), 5.60(\mathrm{~m}, 1 \mathrm{H}), 5.49-5.36(\mathrm{~m}, 2 \mathrm{H}), 4.62-$ $4.41(\mathrm{~m}, 4 \mathrm{H}), 4.00(\mathrm{~s}, 3 \mathrm{H}), 3.71(\mathrm{~s}, 3 \mathrm{H}), 2.54(\mathrm{~m}, 4 \mathrm{H}), 2.33(\mathrm{~m}, 2 \mathrm{H})$, $1.88(\mathrm{~m}, 1 \mathrm{H}) ;{ }^{13} \mathrm{C} \mathrm{NMR}\left(75 \mathrm{MHz}, \mathrm{CDCl}_{3}\right): \delta$ 168.2, 166.0, 165.5, $165.0,164.3,152.3,148.3,145.4,140.9,140.3,133.9,133.5$, $133.4,133.3$, 133.1, 132.0, 129.8, 129.7, 129.2, 128.4, 128.3, 128.3, 128.1, 122.6, 120.6, 118.2, 116.9, 102.2, 100.7, 86.0, 81.8, 75.4, 73.1, 70.9, 68.8, 67.6, 62.7, 60.7, 59.3, 56.6, 49.9, 46.2, 28.0 ppm.

Noscapine glycoconjugate $8 \boldsymbol{e}$. Compound 3 (70 mg, 0.16 $\mathrm{mmol})$, on treatment with azido-sugar $6 \mathrm{e}(58 \mathrm{mg}, 0.19 \mathrm{mmol})$, DIPEA (0.027 mL, $0.16 \mathrm{mmol})$ and $\mathrm{CuI}(15 \mathrm{mg}, 0.07 \mathrm{mmol})$ in dry $\mathrm{CH}_{2} \mathrm{Cl}_{2}(10 \mathrm{~mL})$ at room temperature under argon atmosphere for $12 \mathrm{~h}$ and workup as described in the general procedure, afforded compound 8e as a brown solid (111 mg, yield 94\%); $R_{\mathrm{f}}=0.3$ (60\% ethyl acetate $/ n$-hexane); IR (KBr) cm $\mathrm{cm}^{-1}: 3425,2928$, 2797, 1759, 1622, 1497, 1479, 1376, 1271; ${ }^{1} \mathrm{H}$ NMR $(300 \mathrm{MHz}$, $\left.\mathrm{CDCl}_{3}\right): \delta 7.97(\mathrm{~s}, 1 \mathrm{H}), 7.35(\mathrm{~m}, 5 \mathrm{H}), 6.94(\mathrm{~d}, J=8.4 \mathrm{~Hz}, 1 \mathrm{H}), 6.28$ $(\mathrm{s}, 1 \mathrm{H}), 6.06(\mathrm{~d}, J=8.1 \mathrm{~Hz}, 1 \mathrm{H}), 5.96-5.92(\mathrm{~m}, 3 \mathrm{H}), 5.58-5.29(\mathrm{~m}$, $3 \mathrm{H})$, 4.74-4.39 (m, 7H), 4.01-3.99 (m, 4H), $3.82(\mathrm{~s}, 3 \mathrm{H}), 2.25(\mathrm{~m}$, $4 \mathrm{H}), 2.34-2.31(\mathrm{~m}, 2 \mathrm{H}), 1.89-1.85(\mathrm{~m}, 1 \mathrm{H}), 1.42,1.30$ (each s, $6 \mathrm{H}) ;{ }^{13} \mathrm{C}$ NMR $\left(75 \mathrm{MHz}, \mathrm{CDCl}_{3}\right): \delta 168.1,152.4,148.2,145.4$, $144.4,140.6$, 140.2, 136.8, 133.9, 132.0, 128.5, 128.1, 127.9, $125.0,124.9,120.6,118.0,116.7,111.9,105.0,102.2,102.1$, 100.6, 81.8, 81.6, 81.3, 78.7, 71.8, 67.6, 60.7, 60.5, 59.3, 56.5, 49.8, 48.9, 46.1, 27.9, 26.5, 26.0 ppm; HRMS: calcd for $\mathrm{C}_{39} \mathrm{H}_{42} \mathrm{~N}_{4} \mathrm{NaO}_{11}[\mathrm{M}+\mathrm{Na}]$ : 765.2748; found 765.2742.

Noscapine glycoconjugate $8 f$. Compound 3 (90 $\mathrm{mg}, 0.20$ $\mathrm{mmol})$, on treatment with azido-sugar $6 \mathbf{f}(120 \mathrm{mg}, 0.24 \mathrm{mmol})$, DIPEA $(0.034 \mathrm{~mL}, 0.2 \mathrm{mmol})$ and $\mathrm{CuI}(19 \mathrm{mg}, 0.1 \mathrm{mmol})$ in dry $\mathrm{CH}_{2} \mathrm{Cl}_{2}(10 \mathrm{~mL})$ at room temperature under argon atmosphere for $12 \mathrm{~h}$ and workup as described in the general procedure, afforded compound 8 f as a brown solid (157 mg, yield 85\%); $R_{\mathrm{f}}=0.35$ (60\% ethyl acetate $/ n$-hexane); MS: $m / z 927[\mathrm{M}+\mathrm{H}]^{+}$; IR $(\mathrm{KBr}) \mathrm{cm}^{-1}:$ 2963, 2926, 2855, 1760, 1621, 1496, 1454, 1401, 1261, 1095; ${ }^{1} \mathrm{H}$ NMR (300 MHz, $\left.\mathrm{CDCl}_{3}\right): \delta 7.97$ (s, 1H), 7.25-7.23 $(\mathrm{m}, 15 \mathrm{H}), 6.88(\mathrm{~d}, J=8.4 \mathrm{~Hz}, 1 \mathrm{H}), 6.21(\mathrm{~s}, 1 \mathrm{H}), 6.07(\mathrm{~d}, J=8.1 \mathrm{~Hz}$, $1 \mathrm{H}), 5.83(\mathrm{~s}, 2 \mathrm{H}), 5.54(\mathrm{~m}, 1 \mathrm{H}), 5.40-5.27(\mathrm{~m}, 2 \mathrm{H}), 4.92-4.37(\mathrm{~m}$, $11 \mathrm{H}), 3.95-3.75(\mathrm{~m}, 8 \mathrm{H}), 3.40$ (d, $J=9.6 \mathrm{~Hz}, 1 \mathrm{H}), 3.10(\mathrm{~m}, 3 \mathrm{H})$, 
2.58-1.81 (m, 7H); ${ }^{13} \mathrm{C}$ NMR (75 $\left.\mathrm{MHz}, \mathrm{CDCl}_{3}\right): \delta$ 168.1, 152.5, 148.4 , 145.6, 144.4, 140.7, 140.3, 138.4, 137.9, 133.9, 131.7, $128.4,128.3,128.1,127.9,127.8,127.5,125.4,120.4,118.4$, 116.3, 102.2, 100.7, 97.8, 81.8, 81.6, 79.9, 77.9, 75.6, 74.8, 73.3, 69.0, 67.7, 60.7, 59.2, 56.7, 55.2, 50.6, 49.5, 45.8, 27.5 ppm.

Noscapine glycoconjugate $8 \mathrm{~g}$. Compound 3 (50 $\mathrm{mg}, 0.13$ $\mathrm{mmol})$, on treatment with azido-sugar $6 \mathrm{~g}$ (46 $\mathrm{mg}, 0.16 \mathrm{mmol})$, DIPEA (0.022 mL, $0.13 \mathrm{mmol})$ and CuI (12 mg, $0.06 \mathrm{mmol})$ in dry $\mathrm{CH}_{2} \mathrm{Cl}_{2}(10 \mathrm{~mL})$ at room temperature under argon atmosphere for $14 \mathrm{~h}$ and workup as described in the general procedure, afforded compound $\mathbf{8 g}$ as a brown solid ( $89 \mathrm{mg}$, yield $90 \%$ ); $R_{\mathrm{f}}=$ 0.25 (60\% ethyl acetate/ $n$-hexane); MS: $m / z 745[\mathrm{M}+\mathrm{Na}]^{+}$; IR (KBr) $\mathrm{cm}^{-1}$ : 2988, 2934, 2876, 1764, 1624, 1500, 1479, 1382, 1274; ${ }^{1} \mathrm{H}$ NMR (300 MHz, $\left.\mathrm{CDCl}_{3}\right): \delta 7.98(\mathrm{~s}, 1 \mathrm{H}), 6.87(\mathrm{~d}, J=8.1$ $\mathrm{Hz}, 1 \mathrm{H}), 6.22(\mathrm{~s}, 1 \mathrm{H}), 6.01(\mathrm{~d}, J=8.1 \mathrm{~Hz}, 1 \mathrm{H}), 5.85$ (s, 2H), 5.51$5.31(\mathrm{~m}, 4 \mathrm{H}), 4.56-4.10(\mathrm{~m}, 7 \mathrm{H}), 3.92(\mathrm{~s}, 3 \mathrm{H}), 3.77(\mathrm{~s}, 3 \mathrm{H}), 2.45(\mathrm{~s}$, $3 \mathrm{H}), 2.29-2.26(\mathrm{~m}, 2 \mathrm{H}), 1.98(\mathrm{~d}, J=3.3 \mathrm{~Hz}, 1 \mathrm{H}), 1.82-1.77(\mathrm{~m}$, 1H), 1.43, 1.31, 1.29, 1.20 (each s, $12 \mathrm{H}$ ); ${ }^{13} \mathrm{C}$ NMR (75 MHz, $\left.\mathrm{CDCl}_{3}\right): \delta 168.1,152.2,148.3,144.0,140.8,140.3,133.9,132.0$, 125.3, 120.6, 118.2, 116.7, 109.7, 108.9, 102.3, 102.2, 100.7, 96.0, 81.8, 71.0, 70.6, 70.2, 67.5, 67.0, 60.7, 59.2, 56.6, 50.3, 49.7, 46.1, 27.8, 25.9, 25.9, 24.8, 24.3 ppm.

Noscapine glycoconjugate $8 \boldsymbol{h}$. Compound 3 (100 mg, 0.23 $\mathrm{mmol}$ ), on treatment with azido-sugar $6 \mathbf{j}$ (93 $\mathrm{mg}, 0.28 \mathrm{mmol}$ ), DIPEA (0.039 mL, $0.23 \mathrm{mmol})$ and CuI (21 mg, $0.12 \mathrm{mmol})$ in dry $\mathrm{CH}_{2} \mathrm{Cl}_{2}(10 \mathrm{~mL})$ at room temperature under argon atmosphere for $13 \mathrm{~h}$ and workup as described in the general procedure, afforded compound $\mathbf{8 h}$ as a brown solid (152 $\mathrm{mg}$, yield 86\%); $R_{\mathrm{f}}=0.24$ (60\% ethyl acetate $/ n$-hexane); MS: $m / z 795[\mathrm{M}+\mathrm{Na}]^{+} ; \mathrm{IR}$ (KBr) $\mathrm{cm}^{-1}$ : 3416, 2926, 2854, 1759, 1711, 1622, 1497, 1479, 1457, 1376, 1271; ${ }^{1} \mathrm{H}$ NMR (300 MHz, $\left.\mathrm{CDCl}_{3}\right): \delta 7.96(\mathrm{~s}, 1 \mathrm{H})$, 7.28-7.19 (m, 5H), 6.87 (d, $J=8.4 \mathrm{~Hz}, 1 \mathrm{H}), 6.20(\mathrm{~s}, 1 \mathrm{H}), 5.98$ (d, $J=8.4 \mathrm{~Hz}, 1 \mathrm{H}), 5.87-5.84(\mathrm{~m}, 3 \mathrm{H}), 5.47$ (d, $J=3.6 \mathrm{~Hz}, 1 \mathrm{H}), 5.37-$ $5.22(\mathrm{~m}, 4 \mathrm{H}), 4.73-4.53(\mathrm{~m}, 5 \mathrm{H}), 4.27-4.23(\mathrm{~m}, 2 \mathrm{H}), 3.93(\mathrm{~s}, 3 \mathrm{H})$, 3.78 (s, 3H), 2.40 (s, 3H), 2.29-2.19 (m, 2H), 2.10 (m, 1H), 1.79$1.71(\mathrm{~m}, 1 \mathrm{H}), 1.38,1.24$ (each s, $6 \mathrm{H}) ;{ }^{13} \mathrm{C} \mathrm{NMR}$ (75 MHz, $\mathrm{CDCl}_{3}$ ): $\delta 168.4,152.6,148.3,145.0,143.9,140.5,137.2,133.8,132.0$, $128.5,127.9,125.7,120.9,118.0,116.7,111.9,105.1,102.3$, 102.1, 100.7, 82.2, 81.6, 80.9, 80.5, 72.4, 67.7, 67.1, 60.6, 59.2, 56.4, 54.2, 49.7, 46.1, 27.7, 26.7, $26.2 \mathrm{ppm}$.

Noscapine glycoconjugate 8i. Compound 3 (60 mg, $0.14 \mathrm{mmol}$ ), on treatment with azido-sugar $6 \mathbf{i}(48 \mathrm{mg}, 0.17 \mathrm{mmol})$, DIPEA $(0.022 \mathrm{~mL}, 0.13 \mathrm{mmol})$ and CuI $(12 \mathrm{mg}, 0.06 \mathrm{mmol})$ in dry $\mathrm{CH}_{2} \mathrm{Cl}_{2}(10 \mathrm{~mL})$ at room temperature under argon atmosphere for $12 \mathrm{~h}$ and workup as described in the general procedure, afforded compound $8 \mathbf{i}$ as a brown solid ( $80 \mathrm{mg}$, yield $85 \%$ ); $R_{\mathrm{f}}=$ 0.25 (60\% ethyl acetate/ $n$-hexane); MS: $m / z 747[\mathrm{M}+\mathrm{Na}]^{+}$; IR (KBr) $\mathrm{cm}^{-1}$ : 3416, 2926, 2854, 1759, 1711, 1622, 1497, 1479, 1457, 1376, 1271; ${ }^{1} \mathrm{H}$ NMR (300 MHz, $\mathrm{CDCl}_{3}$ ): $\delta 8.06(\mathrm{~s}, 1 \mathrm{H}), 6.98$ $(\mathrm{d}, J=8.4 \mathrm{~Hz}, 1 \mathrm{H}), 6.33-6.17(\mathrm{~m}, 2 \mathrm{H}), 5.95-5.92(\mathrm{~m}, 3 \mathrm{H}), 5.61(\mathrm{~d}$, $J=7.8 \mathrm{~Hz}, 1 \mathrm{H}), 5.44-5.31(\mathrm{~m}, 2 \mathrm{H}), 4.73(\mathrm{~d}, J=11.7 \mathrm{~Hz}, 1 \mathrm{H}), 4.57$ $(\mathrm{m}, 1 \mathrm{H}), 4.42-4.31(\mathrm{~m}, 3 \mathrm{H}), 4.02-3.86(\mathrm{~m}, 8 \mathrm{H}), 3.59-3.48(\mathrm{~m}$, $3 \mathrm{H}), 2.55-2.51(\mathrm{~m}, 4 \mathrm{H}), 2.41-2.38(\mathrm{~m}, 2 \mathrm{H}), 2.07-1.94(\mathrm{~m}, 1 \mathrm{H})$, 1.64-157 (m, 2H), 1.46, 1.32 (each s, 6H), 0.91 (t, $J=7.2 \mathrm{~Hz}, 3 \mathrm{H})$; ${ }^{13} \mathrm{C}$ NMR (75 MHz, $\mathrm{CDCl}_{3}$ ): $\delta 158.8,152.6,148.4,145.1,143.9$, $140.5,140.3,133.9,125.8,118.5,118.1,116.8,111.8,105.2$,
102.3, 102.2, 100.7, 82.2, 82.0, 81.6, 80.4, 72.4, 68.0, 67.1, 60.6, 59.2, 56.5, 54.2, 49.6, 45.9, 27.6, 26.7, 26.2, 22.9, 10.5 .

Noscapine glycoconjugate 8j. Compound $3(100 \mathrm{mg}, 0.23$ $\mathrm{mmol}$ ), on treatment with azido-sugar $6 \mathbf{j}(88 \mathrm{mg}, 0.28 \mathrm{mmol})$, DIPEA (0.039 mL, $0.23 \mathrm{mmol})$ and $\mathrm{CuI}(21 \mathrm{mg}, 0.12 \mathrm{mmol})$ in dry $\mathrm{CH}_{2} \mathrm{Cl}_{2}(10 \mathrm{~mL})$ at room temperature under argon atmosphere for $12 \mathrm{~h}$ and workup as described in the general procedure, afforded compound $\mathbf{8 j}$ as a brown solid (138 mg, yield 80\%); $R_{\mathrm{f}}=0.25$ (60\% ethyl acetate $/ n$-hexane); MS: $m / z 775[\mathrm{M}+\mathrm{Na}]^{+} ; \mathrm{IR}$ $(\mathrm{KBr}) \mathrm{cm}^{-1}$ : 3416, 2928, 2854, 1759, 1717, 1622, 1497, 1479, 1460, 1376, 1271; ${ }^{1} \mathrm{H}$ NMR (300 MHz, $\left.\mathrm{CDCl}_{3}\right): \delta 8.06(\mathrm{~s}, 1 \mathrm{H}), 6.99$ $(\mathrm{d}, J=8.4 \mathrm{~Hz}, 1 \mathrm{H}), 6.29-6.20(\mathrm{~m}, 2 \mathrm{H}), 5.93-5.90(\mathrm{~m}, 3 \mathrm{H}), 5.62(\mathrm{~d}$, $J=3.3 \mathrm{~Hz}, 1 \mathrm{H}), 5.45-5.31(\mathrm{~m}, 2 \mathrm{H}), 4.77(\mathrm{~d}, J=12.6 \mathrm{~Hz}, 1 \mathrm{H})$, 4.56-4.25 (m, 5H), 3.98-3.86 (m, 7H), 3.68-3.49 (m, 3H, OH, $\left.\mathrm{OCH}_{2}\right), 2.68-2.40(\mathrm{~m}, 5 \mathrm{H}), 2.20-2.12(\mathrm{~m}, 1 \mathrm{H}), 1.69-1.61(\mathrm{~m}, 2 \mathrm{H})$, 1.51-1.46 (m, 4H), 1.32 (s, 3H), 0.89 (d, $J=7.6 \mathrm{~Hz}, 6 \mathrm{H}) ;{ }^{13} \mathrm{C} \mathrm{NMR}$ $\left(75 \mathrm{MHz}, \mathrm{CDCl}_{3}\right): \delta 168.1,152.6,148.7,145.2,144.0,140.3$, 140.3 , 133.9, 125.6, 118.6, 118.3, 111.8, 105.2, 105.1, 102.3, 100.8, 82.3, 82.1, 80.4, 69.1, 67.4, 67.3, 60.8, 60.6, 56.7, 54.1, 38.4, 26.8, 26.7, 26.2, 24.9, 22.5, 22.4 ppm.

Noscapine glycoconjugate $8 \boldsymbol{k}$. Compound 3 (65 mg, 0.15 $\mathrm{mmol}$ ), on treatment with azido-sugar 6k (64 $\mathrm{mg}, 0.18 \mathrm{mmol}$ ), DIPEA (0.025 mL, $0.14 \mathrm{mmol})$ and CuI (15 mg, $0.08 \mathrm{mmol})$ in dry $\mathrm{CH}_{2} \mathrm{Cl}_{2}(10 \mathrm{~mL})$ at room temperature under argon atmosphere for $14 \mathrm{~h}$ and workup as described in the general procedure, afforded compound 8k as a brown solid (97 mg, yield $82 \%$ ); $R_{\mathrm{f}}=$ 0.2 (80\% ethyl acetate/ $n$-hexane); MS: $m / z 820[\mathrm{M}+\mathrm{Na}]^{+}$; IR (KBr) $\mathrm{cm}^{-1}$ : 3426, 2987, 2937, 2926, 1759, 1622, 1497, 1479, 1382, 1271; ${ }^{1} \mathrm{H}$ NMR (300 MHz, $\left.\mathrm{CDCl}_{3}\right): \delta 7 . ;{ }^{13} \mathrm{C} \mathrm{NMR}(75 \mathrm{MHz}$, $\left.\mathrm{CDCl}_{3}\right): \delta 168.1,152.5,152.4,148.3,148.3,145.3,145.2,144.3$, $144.1,140.5$, 140.4, 140.2, 133.8, 131.8, 131.6, 125.7, 125.2, 120.5 , 118.2, 116.5, 116.3, 111.7, 109.3, 109.2, 105.5, 105.3, 102.1, 100.6, 83.8, 83.1, 82.2, 81.6, 81.3, 81.1, 81.0, 72.7, 72.5, 72.2 , 71.0, 69.3, 68.6, 67.6, 67.5, 60.5, 59.2, 56.5, 53.3, 52.6, 52.3, 49.6, 49.3, 46.0, 45.7, 27.6, 27.1, 26.6, 26.0, 25.0, 25.0 ppm.

Noscapine glycoconjugate $8 \mathbf{l}$. Compound 3 ( $90 \mathrm{mg}, 0.21 \mathrm{mmol}$ ), on treatment with azido-sugar 61 ( $89 \mathrm{mg}, 0.25 \mathrm{mmol})$, DIPEA $(0.035 \mathrm{~mL}, 0.2 \mathrm{mmol})$ and $\mathrm{CuI}(19 \mathrm{mg}, 0.1)$ in dry $\mathrm{CH}_{2} \mathrm{Cl}_{2}(10 \mathrm{~mL})$ at room temperature under argon atmosphere for $14 \mathrm{~h}$ and workup as described in the general procedure, afforded compound 81 as a brown solid (140 mg, yield 84\%); $R_{\mathrm{f}}=0.2$ (80\% ethyl acetate/ $n$-hexane); MS: $m / z 820[\mathrm{M}+\mathrm{Na}]^{+}$; IR (KBr) $\mathrm{cm}^{-1}$ : 3439, 2988, 2925, 2853, 1759, 1622, 1497, 1461, 1384, 1272,$1069 ;{ }^{1} \mathrm{H}$ NMR $\left(300 \mathrm{MHz}, \mathrm{CDCl}_{3}\right): \delta 8.04(\mathrm{~s}, 1 \mathrm{H}), 6.89(\mathrm{~d}, J=$ $8.4 \mathrm{~Hz}, 1 \mathrm{H}), 6.22(\mathrm{~s}, 1 \mathrm{H}), 6.02(\mathrm{~m}, 1 \mathrm{H}), 5.85(\mathrm{~s}, 2 \mathrm{H}), 5.51-5.22(\mathrm{~m}$, $5 \mathrm{H}), 4.52-4.00(\mathrm{~m}, 7 \mathrm{H}), 3.92(\mathrm{~s}, 3 \mathrm{H}), 3.78(\mathrm{~s}, 3 \mathrm{H}), 3.61-3.47(\mathrm{~m}$, $5 \mathrm{H}), 2.44-2.27(\mathrm{~m}, 5 \mathrm{H}), 1.96-1.80(\mathrm{~m}, 2 \mathrm{H}), 1.46-1.26$ (merge $4 \mathrm{~s}$, $12 \mathrm{H}) ;{ }^{13} \mathrm{C} \mathrm{NMR}\left(75 \mathrm{MHz}, \mathrm{CDCl}_{3}\right): \delta 168.2,152.6,148.4,145.3$, $140.6,140.3$, 133.9, 131.9, 131.5, 125.4, 120.6, 118.3, 118.2, 109.3, 108.6, 102.3, 102.2, 100.7, 96.2, 81.6, 81.1, 72.7, 72.2, 71.0, 70.5, 70.1, 69.2, 67.4, 66.8, 60.6, 60.8 59.3, 56.6, 52.9, 49.6, 49.0, 46.0, 45.5, 27.6, 26.6, 26.0, 25.9, 24.8, 24.4 ppm.

Noscapine glycoconjugate $8 \mathrm{~m}$. Compound $3(50 \mathrm{mg}, 0.11$ $\mathrm{mmol})$, on treatment with azido-sugar $6 \mathrm{~m}(50 \mathrm{mg}, 0.13 \mathrm{mmol})$, DIPEA (0.018 mL, $0.14 \mathrm{mmol})$ and CuI (10 mg, $0.05 \mathrm{mmol})$ in dry $\mathrm{CH}_{2} \mathrm{Cl}_{2}(10 \mathrm{~mL})$ at room temperature under argon atmosphere for $15 \mathrm{~h}$ and workup as described in the general procedure, 
afforded compound $\mathbf{8 m}$ as a brown solid (80 $\mathrm{mg}$, yield 90\%); $R_{\mathrm{f}}=0.2$ (80\% ethyl acetate/ $n$-hexane); MS: $m / z 817[\mathrm{M}+\mathrm{H}]^{+}$; IR $(\mathrm{KBr}) \mathrm{cm}^{-1}$ : 3417, 2926, 1759, 1622, 1497, 1479, 1456, 1272; ${ }^{1} \mathrm{H}$ NMR (300 MHz, $\left.\mathrm{CDCl}_{3}\right): \delta 8.08(\mathrm{~s}, 1 \mathrm{H}), 7.30(\mathrm{~m}, 5 \mathrm{H}), 6.96(\mathrm{~d}, J=$ $8.1 \mathrm{~Hz}, 1 \mathrm{H}), 6.30(\mathrm{~s}, 1 \mathrm{H}), 6.11(\mathrm{~d}, \mathrm{~J}=5.7 \mathrm{~Hz}, 1 \mathrm{H}), 5.93(\mathrm{~s}, 2 \mathrm{H})$, 5.49-5.29 (m, 2H), 4.70-4.30 (m, 7H), 4.13-3.51 (m, 13H), 2.512.35 (m, 5H), 2.04-1.93 (m, 2H), 1.49, 1.32 (each s, 6H); ${ }^{13} \mathrm{C}$ NMR (75 $\left.\mathrm{MHz}, \mathrm{CDCl}_{3}\right): \delta 168.2,152.7,148.5,144.2,140.4,140.2$, $137.3,128.5,127.9,127.6,125.8,120.5,118.4$, 118.2, 111.7, 105.0, 102.2, 102.2, 100.7, 82.1, 81.7, 81.1, 79.1, 72.5, 71.8, 69.3, $67.2,60.7,60.4,59.3,56.6,53.3,53.0,49.6,48.9,45.9,45.4,27.6$, 26.8, 26.5, $26.2 \mathrm{ppm}$.

\section{Acknowledgements}

The authors gratefully acknowledge the Council of Scientific \& Industrial Research, New Delhi (grant no. 02(0173)/13/EMR-II) for funding and CISC, Banaras Hindu University and RSIC, Central Drug Research Institute, Lucknow for providing the spectroscopic data of the developed molecules.

\section{References}

1 (a) B. B. Mishra and V. K. Tiwari, Eur. J. Med. Chem., 2011, 46, 4769; (b) G. Jurjens, A. Kirschning and D. A. Candito, Nat. Prod. Rep., 2015, 32, 723-737.

2 (a) P. M. Checchi, J. H. Nettles, J. Zhou, J. P. Snyder and H. C. Joshi, Trends Pharmacol. Sci., 2003, 24, 361; (b) M. A. Jordan and L. Wilson, Nat. Rev. Cancer, 2004, 4, 253.

3 C. Warolin and P. J. Robiquet, Rev. Hist. Pharm., 1999, 47, 97.

4 B. Dahlstrom, T. Mellstrand, C. G. Lofdahl and M. Johansson, Eur. J. Clin. Pharmacol., 1982, 22, 535.

5 K. Ye, Y. Ke, N. Keshava, J. Shanks, J. A. Kapp, R. R. Tekmal, J. Petros and H. C. Joshi, Proc. Natl. Acad. Sci. U. S. A., 1998, 95, 1601.

6 K. Ye, Y. Ke, N. Keshava, J. Shanks, J. A. Kapp and R. R. Tekmal, et al., Proc. Natl. Acad. Sci. U. S. A., 1998, 95, 1601.

7 Y. Ke, K. Ye, H. E. Grossniklaus, D. R. Archer, H. C. Joshi and J. A. Kapp, Cancer Immunol. Immunother., 2000, 49, 217.

8 B. Sung, K. S. Ahn and B. B. Aggarwal, Cancer Res., 2010, 70, 3259.

9 J. W. Landen, R. Lang, S. J. McMahon, N. M. Rusan, A. M. Yvon and A. W. Adams, Cancer Res., 2002, 62, 4109.

10 J. Zhou, K. Gupta, J. Yao, K. Ye, D. Panda and P. Giannakakou, J. Biol. Chem., 2002, 277, 39777.

11 J. W. Landen, V. Hau, M. Wang, T. Davis, B. Ciliax and B. H. Wainer, Clin. Cancer Res., 2004, 10, 5187.

12 R. Aneja, M. Lopus, J. Zhou, S. N. Vangapandu, A. Ghaleb and J. Yao, Cancer Res., 2006, 66, 3782.

13 T. Jackson, M. B. Chougule, N. Ichite, R. R. Patlolla and M. Singh, Cancer Chemother. Pharmacol., 2008, 63, 117.

14 R. Aneja, A. M. Ghaleb, J. Zhou, V. W. Yang and H. C. Joshi, Cancer Res., 2007, 67, 3862.

15 (a) K. Ye, Y. Ke, N. Keshava, J. Shanks, J. A. Kapp, R. R. Tekmal, J. Petros and H. C. Joshi, Proc. Natl. Acad. Sci. U. S. A., 1998, 95, 1601; (b) H. C. Joshi and J. Zhou,
Drug News Perspect., 2000, 13, 543; (c) Y. Ke, K. Ye, H. E. Grossniklaus, D. R. Archer, H. C. Joshi and J. A. Kapp, Cancer Immunol. Immunother., 2000, 49, 217.

16 J. T. Anderson, A. E. Ting, S. Boozer, K. Brunden, C. Crumrine and J. Danzig, J. Med. Chem., 2005, 48, 7096.

17 (a) J. T. Anderson, A. E. Ting, S. Boozer, K. R. Brunden, J. Danzig and T. Dent, J. Med. Chem., 2005, 48, 2756; (b) R. C. Mishra, P. Karna, S. R. Gundala, V. R. Pannu, A. Stanton, K. K. Gupta, M. H. Robinson, M. Lopus, L. Wilson, M. Henary and R. Aneja, Biochem. Pharmacol., 2011, 82, 110.

18 (a) S. Dedola, S. A. Nepogodiev and R. A. Field, Org. Biomol. Chem., 2007, 5, 1006; (b) V. K. Tiwari, R. C. Mishra, A. Sharma and R. P. Tripathi, Mini-Rev. Med. Chem., 2012, 12, 1497.

19 (a) T. K. Dam and C. F. Brewer, Glycobiology, 2010, 20, 270; (b) A. Imberty, E. P. Mitchell and M. Wimmerova, Curr. Opin. Struct. Biol., 2005, 15, 525.

20 B. J. J. Davis, J. Chem. Soc., Perkin Trans. 1, 1999, 3215.

21 H. C. Kolb, M. G. Finn and K. B. Sharpless, Angew. Chem., Int. Ed., 2001, 40, 2004.

22 (a) R. Huisgen, Angew. Chem., Int. Ed., 1963, 2, 565; (b) C. W. Meldal, C. Tornoe and M. Meldal, J. Org. Chem., 2002, 67, 3057; (c) V. V. Rostovtsev, L. G. Green, V. V. Fokin and K. B. Sharpless, Angew. Chem., Int. Ed., 2002, 41, 2596.

23 (a) J. E. Hein and V. V. Fokin, Chem. Soc. Rev., 2010, 39, 1302; (b) M. Meldal and C. W. Tornoe, Chem. Rev., 2008, 108, 2952. 24 H. C. Kolb and K. B. Sharpless, Drug Discovery Today, 2003, 8, 1128.

25 F. Amblard, J. H. Cho and R. F. Schinazi, Chem. Rev., 2009, 109, 4207.

26 G. C. Tron, T. Pirali, R. A. Billington, P. L. Canonico, G. Sorba and A. A. Genazzani, Med. Res. Rev., 2008, 28, 278.

27 (a) A. Dumont, A. Malleron, M. Awwad, S. Dukan and B. Vauzeilles, Angew. Chem., Int. Ed., 2012, 51, 3143; (b) A. Niederwieser, A. K. Späte, L. D. Nguyen, C. Jüngst, W. Reutter and V. Wittmann, Angew. Chem., Int. Ed., 2013, 52, 4265; (c) A. Pathigoolla, R. G. Gonnade and K. M. Sureshan, Angew. Chem., Int. Ed., 2012, 51, 4362.

28 P. Thirumurugan, D. Matosiuk and K. Jozwiak, Chem. Rev., 2013, 113, 4905.

29 (a) D. Kumar, A. Mishra, B. B. Mishra, S. Bhattacharya and V. K. Tiwari, J. Org. Chem., 2013, 78, 899; (b) D. Kumar, B. B. Mishra and V. K. Tiwari, J. Org. Chem., 2014, 79, 251.

30 (a) V. K. Tiwari, A. Kumar and R. R. Schmidt, Eur. J. Org. Chem., 2012, 2945; (b) V. Prasad, R. R. Kale, B. B. Mishra, D. Kumar and V. K. Tiwari, Org. Lett., 2012, 14, 2936.

31 (a) P. Dwivedi, K. B. Mishra, B. B. Mishra, N. Singh, R. K. Singh and V. K. Tiwari, Glycoconjugate J., 2015, 32, 127-140; (b) D. Kushwaha, P. Pandey, R. R. Kale and V. K. Tiwari, Trends Carbohydr. Res., 2012, 4(3), 45; (c) K. B. Mishra and V. K. Tiwari, J. Org. Chem., 2014, 79, 5752. 32 (a) D. Kushwaha and V. K. Tiwari, J. Org. Chem., 2013, 78, 8184; (b) K. B. Mishra and V. K. Tiwari, J. Org. Chem., 2014, 79, 5752; (c) A. Mishra and V. K. Tiwari, J. Org. Chem., 2015, 80, 4869; (d) A. Mishra, B. B. Mishra and V. K. Tiwari, RSC Adv., 2015, 5, 41520. 
33 D. Kumar, K. B. Mishra, B. B. Mishra, S. Mondal and V. K. Tiwari, Steroids, 2014, 80, 71.

34 S. K. Rai, S. Khanam, R. S. Khanna and A. K. Tewari, Cryst. Growth Des., 2015, 15, 1430.
35 G. R. Desiraju, Crystal Engineering: The Design of Organic Solids, Elsevier, Amsterdam, 1989.

36 (a) G. R. Desiraju, J. Am. Chem. Soc., 2013, 135, 9952; (b) G. R. Desiraju, Angew. Chem., Int. Ed., 2007, 46, 8342. 